\title{
Hypoxia Inducible Factor-1 $\alpha$ Inhibition in Von Hippel Lindau-mutant Malignant Pleural Mesothelioma Cells
}

\author{
TAKEHITO SHUKUYA ${ }^{1,2,3}$, JUN OYANAGI ${ }^{4}$, MASAKUNI SERIZAWA ${ }^{2}$, \\ MASARU WATANABE ${ }^{2,4}$, NOBUYUKI YAMAMOTO ${ }^{1,4}$ and YASUHIRO $\mathrm{KOH}^{2,4}$ \\ ${ }^{1}$ Division of Thoracic Oncology, Shizuoka Cancer Center, Shizuoka, Japan; \\ ${ }^{2}$ Drug Discovery and Development Division, Shizuoka Cancer Center Research Institute, Shizuoka, Japan; \\ ${ }^{3}$ Department of Respiratory Medicine, Juntendo University, Tokyo, Japan; \\ ${ }^{4}$ Internal Medicine III, Wakayama Medical University, Wakayama, Japan
}

\begin{abstract}
Background/Aim: Molecular targeted agents have been successfully developed against solid tumors and their use is also being investigated for the treatment of malignant pleural mesothelioma (MPM). We have previously reported von Hippel Lindau (VHL) mutations detected by massive parallel sequencing technology in samples of patients with $M P M$. Here, we conducted an in vitro study to investigate the therapeutic approaches in VHL-mutant MPM. Materials and Methods: Three MPM cell lines with or without a VHL mutation were used and the effects of molecular-targeted agents on growth inhibition were evaluated. Based on the characteristics of the molecular targeted agents that exhibited growth inhibitory effect, the effects of knockdown by siRNA were also evaluated. Results: NCI-H28 MPM cells harboring the VHL L89H mutation were sensitive to $Y C-1$, known as an inhibitor of hypoxia inducible factor (HIF)-1 $\alpha$, and $Y C$ Itreatment induced massive apoptosis in a dose-and-timedependent manner. Knockdown of HIF-1 $\alpha$ by siRNA partially inhibited the growth of NCI-H28 cells, suggesting that an additional blockade may be required to completely inhibit growth signaling. Conclusion: The VHL mutation may predict tumor responses to $\mathrm{YC}-1$, a HIF-1 1 inhibitor.
\end{abstract}

Malignant pleural mesothelioma (MPM) is an aggressive type of neoplasms arising from the pleural cavity $(1,2)$. It has been reported that about $80 \%$ of MPM cases are related to asbestos exposure (3). Genetic predisposition, simian Virus 40 infection

This article is freely accessible online.

Correspondence to: Yasuhiro Koh, MD, Ph.D., Internal Medicine III, 811-1 Kimiidera, Wakayama 641-8509, Japan. Tel: +81 734410619, Fax: +81 734462877, e-mail: ykoh@wakayama-med.ac.jp

Key Words: Malignant pleural mesothelioma, von Hippel Lindau mutation, Hypoxia inducible factor- $1 \alpha$, molecular targeted therapy.
(SV40), radiotherapy, and exposure to fibers with physical properties similar to asbestos, may trigger to MPM development (4-7). As MPM patients are typically diagnosed at advanced stages of cancer, which are mostly unresponsive to conventional chemotherapy, the prognosis remains poor. The median survival of patients with MPM ranges from 9 to 12 months, regardless of treatment with chemotherapy combining cisplatin and pemetrexed or raltitrexed $(8,9)$.

Recently, molecular targeted therapy has gained much attention. In cancers such as non-small-cell lung cancer and breast cancer, somatic mutations and gene amplifications are thought to be oncogenic, and treatment with inhibitors specific to tumors with such drivers are beneficial for survival (10) and efforts are being undertaken to assess the genetic abnormalities in solid tumors (11-13).

Recently, immune checkpoint inhibitors have shown immense efficacy in various malignancies. Nivolumab elicits significant effects in patients with MPM and has been approved for the treatment of MPM in Japan $(14,15)$. Despite these advances, improvements in chemotherapy, especially with respect to molecular targeted agents for MPM treatment, are quite slow, partly because the number of patients is small. However, thus far, several studies on the genetic alterations in MPM have been published. A homozygous deletion in PTEN was detected in two of 21 MPM cell lines and this mutation was related to Akt activation $(16,17)$. Thomas et al. have reported NRAS mutations in three of 37 patients with mesothelioma (18). Approximately $40 \%$ of MPM cases harbor inactivating mutations in neurofibromatosis 2 (NF2) gene, and BAPl loss and/or mutation have been detected in $42 \%$ of MPM patients (19). We have previously reported genetic alterations detected by massive parallel sequencing technology, and 16 genetic mutations including two VHL mutations were detected in 21 specimens from patients with MPM (20). More comprehensive genome-based mutational analysis was also conducted, and loss of CDKN2A/B was reported in MPM and malignant peritoneal mesothelioma 
(21). Inflammation-related biomarkers on survival of MPM patients were also reported (22).

$V H L$, known as a tumor suppressor gene, is located on chromosome $3 \mathrm{p} 25$ and the protein product of $V H L$, i.e., $\mathrm{pVHL}$, has multiple functions. The most well-studied function of $V H L$ is its ability to target HIFs for polyubiquitination and proteasomal degradation via substrate recognition as part of the ubiquitin ligase complex (23). Sekido et al. have reported a VHL mutation in NCI-H28, a mesothelioma cell line (24). Based on these findings, we investigated $V H L$ mutations as potential targets for HIF- $1 \alpha$ inhibition in MPM treatment.

\section{Materials and Methods}

Cell culture and reagents. Human malignant mesothelioma cell lines MSTO-211H, NCI-H2052, and NCI-H28 were purchased from ATCC (Manassas, VA, USA). These cell lines were maintained in RPMI1640 (Invitrogen, Carlsbad, CA, USA) supplemented with 10\% heat-inactivated fetal bovine serum (FBS; Invitrogen) in humidified air containing $5 \% \mathrm{CO}_{2}$ at $37^{\circ} \mathrm{C}$. The cells were incubated under anaerobic conditions with Anaeropack Kenki 5\% (Mitsubishi Gas Chemical Co., Tokyo, Japan), providing a hypoxic condition with approximately $5 \% \mathrm{CO}_{2}$ and less than $1 \% \mathrm{O}_{2}$. Cobaltous chloride $\left(\mathrm{CoCl}_{2}\right)$ was purchased from Wako Pure Chemical Industries (Osaka, Japan). The following anti-cancer drugs were purchased from the indicated companies: gefitinib (Tocris Bioscience, Ellisville, MO, USA); erlotinib, lapatinib, crizotinib, vandetanib selumetinib, and trametinib (LC Laboratories, Woburn, MA, USA); afatinib, dabrafenib, and MK-2206 (Selleck Chemicals, Houston, TX, USA); and YC-1 (Calbiochem, La Jolla, CA, USA).

DNA and RNA extraction. Genomic DNA was extracted from the cell lines using the QIAamp DNA FFPE kit (QIAGEN, Hilden, Germany) according to the manufacturer's instructions. The DNA concentration was quantified using the Quant-iT PicoGreen dsDNA assay kit (Invitrogen).

Amplicon-based next-generation sequencing and variant call. A multiplexed amplicon-based next generation sequencing was performed using the TruSeq amplicon-cancer panel (TSACP; Illumina, San Diego, CA, USA), designed to identify somatic mutations in 48 cancer-related genes according to the manufacturer's instructions. Paired-end sequencing was carried out on an Illumina MiSeq platform with the MiSeq reagent kit v1 or v2 (300-cycles) (Illumina) with a $1,900 \times$ average coverage.

Data processing was conducted using CLC Genomics Workbench version 6.0.3 (CLC bio, Aarhus, Denmark). Quality-trimmed sequence reads were mapped to the human genome (hg19). Nonsynonymous somatic mutations were extracted using COSMIC and hg19 CDS file followed by the elimination of germline mutations using HapMap, 1000 genomes, and dbSNP Final variant calls were made based on the following criteria: frequency $\geq 5 \%$ or over 40 counts of a mutated allele with coverage 500 or more.

In vitro growth-inhibition assay. The growth-inhibitory effect of each inhibitor was evaluated using the 3-(4,5-dimethylthiazol-2-yl)-2,5diphenyltetrazolium (MTT) assay as described previously (25). Briefly, an exponentially growing cell suspension was seeded into each well of a 96-well plate at the density of 2,000-3,000 cells per well. After overnight culture, the cells were treated with each inhibitor at various concentrations and cultured at $37^{\circ} \mathrm{C}$ in a humidified atmosphere for 72 h. Then, MTT solution was added and the plates were further incubated for $4 \mathrm{~h}$ at $37^{\circ} \mathrm{C}$. After centrifuging the plates, cells were dissolved in dimethyl sulfoxide. Optical density was measured at 562 and $630 \mathrm{~nm}$ using a microplate reader (Bio-Rad, Hercules, CA, USA).

Immunoblot analysis. Cells were washed with iced-cold PBS and lysed with M-PER lysis buffer supplemented with Halt protease inhibitor cocktail and Halt phosphatase inhibitor cocktail (Pierce Chemical Co., Rockford, IL, USA). The protein concentration of the lysate was measured using the BCA protein assay reagent (Pierce). Equal amounts of protein $(20 \mu \mathrm{g})$ were separated by SDS-PAGE and then transferred onto nitrocellulose membranes (Bio-Rad) and detected as previously described (20). Antibodies against phospho-EGFR, Akt, phospho-Akt, ERK1/2, phospho-ERK1/2, S6 ribosomal protein, phospho-S6 ribosomal protein, PARP, cleaved-PARP, caspase-3, cleaved-caspase-3, and phospho-MET were purchased from Cell Signaling Technology (Danvers, MA, USA). Antibodies specific for GLUT1 and ENO, HIF-1 $\alpha$, and MET were purchased from Abcam (Cambridge, UK), BD Biosciences (Franklin Lakes, NJ, USA), and Santa Cruz Biotechnology (Santa Cruz, CA, USA), respectively.

APO-BRDU assay. Apoptosis was measured by the TUNEL assay using the APO-BRDU assay kit (Phoenix Flow Systems, San Diego, CA, USA). The cells were treated with or without YC-1 for 24 or $48 \mathrm{~h}$. After the treatment, the cells were harvested, fixed, and stained according to the manufacturer's instructions. Data were acquired using an AccuriC6 flow-cytometer (BD Biosciences, Franklin Lakes, NJ, USA).

Small interfering RNA (siRNA) transfection. siRNA targeting HIF$1 \alpha$ and siRNA Negative Control Med GC Duplex \#2 were purchased from Invitrogen. The target sequence of HIF-1 $\alpha$ was 5'CCAGCCGCTGGAGACACAA TCATAT-3'. These siRNAs were diluted to $0.4 \mu \mathrm{M}$ with $250-\mu \mathrm{l}$ Opti-MEM medium (Invitrogen). Five microliters of Lipofectamine 2000 (Invitrogen) was diluted with 250- $\mu$ l Opti-MEM medium (Invitrogen). Diluted siRNA molecules were gently mixed with diluted Lipofectamine 2000 (Invitrogen) and incubated for $20 \mathrm{~min}$ at $25^{\circ} \mathrm{C}$. Subsequently, $1.25 \times 10^{5}$ cells in $500 \mu \mathrm{l}$ of $10 \%$ FBS medium were gently mixed with $500 \mu \mathrm{l}$ of siRNA-Lipofectamine 2000 complexes and incubated for $10 \mathrm{~min}$ at $25^{\circ} \mathrm{C}$. The resulting mixtures were seeded into 6 -well plates. After incubation for $24 \mathrm{~h}$, the medium was replaced with $10 \%$ FBS medium. The growth-inhibitory effect of HIF- $1 \alpha$ knockdown was assessed with cell counting. The cells were trypsinized and the cell number was counted using the Scepter 2.0 handheld automated cell counter (Millipore, Bedford, MA, USA).

Statistical analysis. $p$-values $<0.05$ were set to indicate statistically significant differences. All statistical analyses were conducted using GraphPad Prism version 5.0 for Windows (GraphPad Software, San Diego, CA, USA).

\section{Results}

Confirmation of VHL mutation in MPM cell lines. Previously, we have found two VHL mutations in 21 samples from patients with MPM (16). To investigate whether the prevalence of $V H L$ mutations is a potential target for MPM 
A

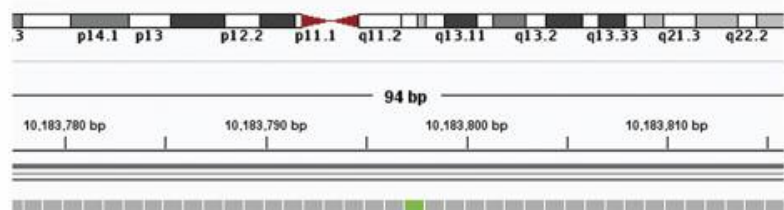

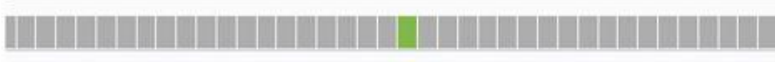

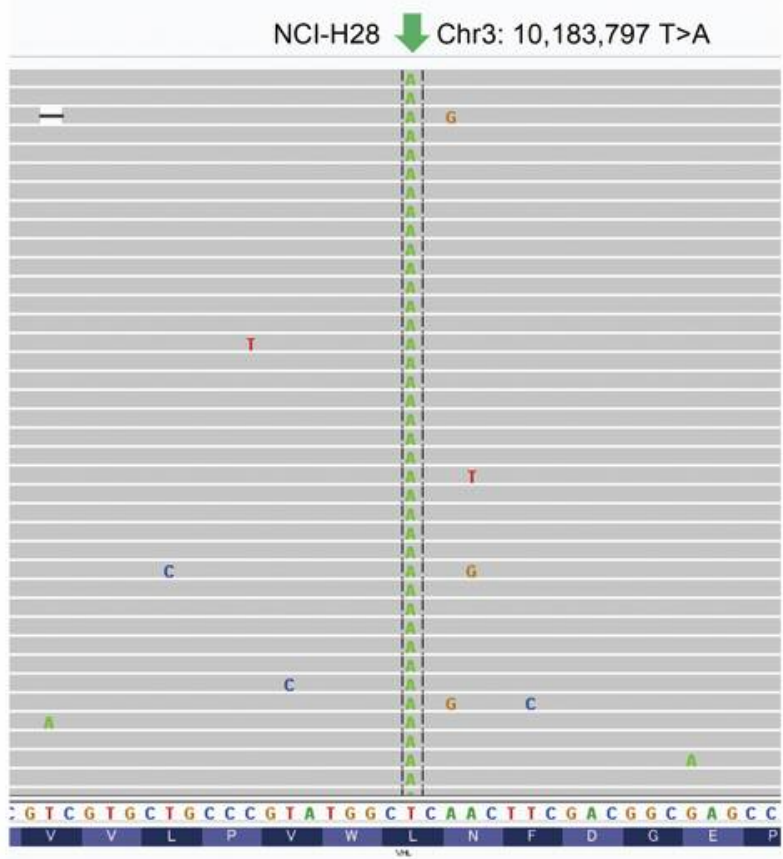

B

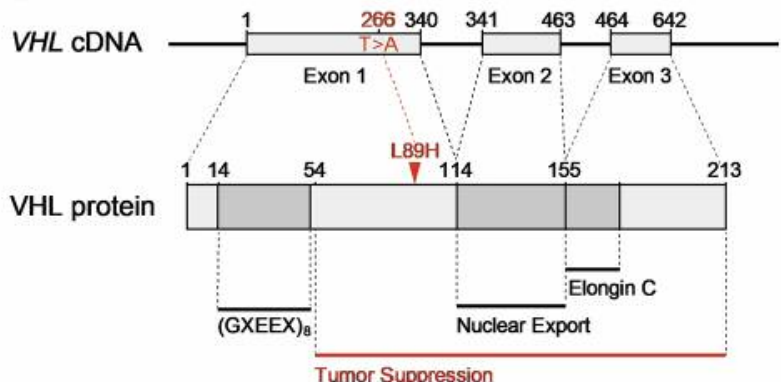

Figure 1. A VHL mutation was found in the NCI-H28 cell line. (A) Detection of the VHL L89H mutation in the NCI-H28 cell line by amplicon-based massive parallel sequencing. (B) VHL gene and protein structure. The missense mutation found in the NCI-H28 cell line is shown in red.

treatment, we first investigated actionable mutations in 48 cancer-related genes by massive parallel sequencing. As shown in Figure 1A, the missense mutation changing the leucine-89 residue to histidine ( $\mathrm{p} . \mathrm{Leu} 89 \mathrm{His}$ ) was confirmed in NCI-H28 cells. The mutation was located in the middle of
A

$\underline{\text { MSTO-211H }} \stackrel{\text { NCl-H2052 }}{\text { NCl-H28 }}$

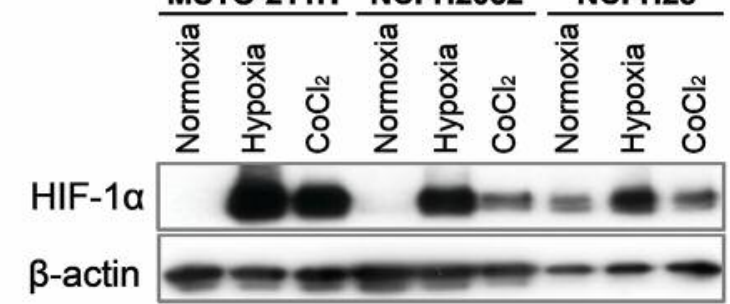

B

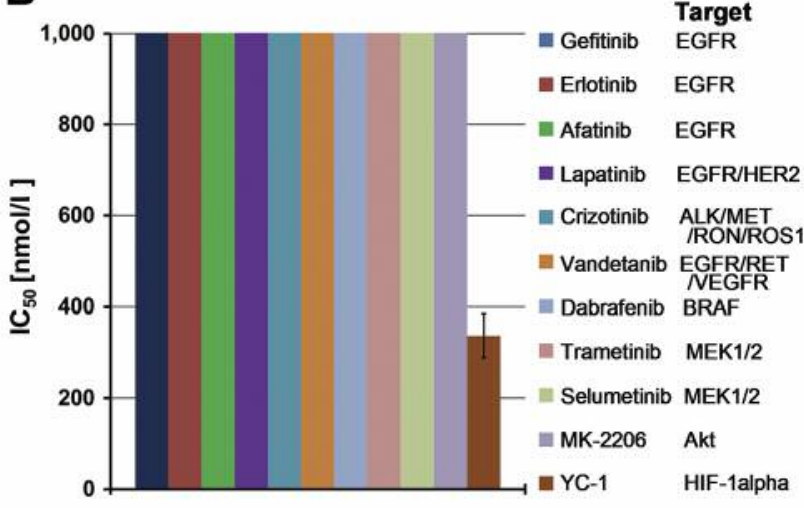

C

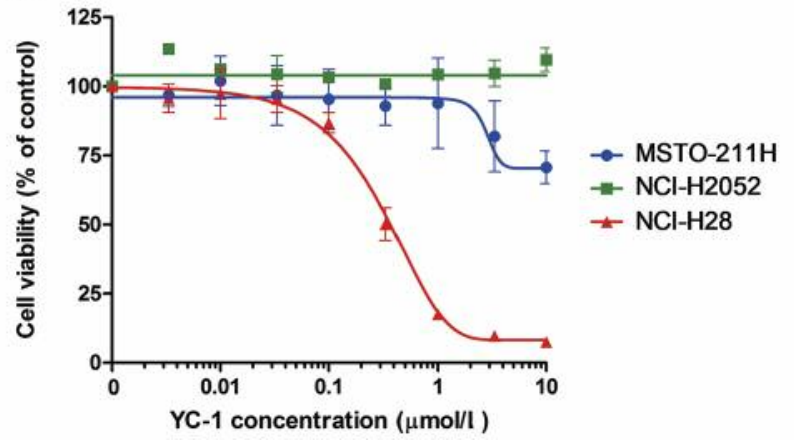

Figure 2. NCI-H28 cells overexpressing HIF-1 $\alpha$ protein under normoxic conditions were sensitive to $Y C-1$, a HIF-1 $\alpha$ inhibitor. (A) Expression levels of HIF-1 $\alpha$ in MPM cell lines. Overexpression of HIF-1 $\alpha$ was inducible under hypoxic conditions and CoCl2-induced hypoxiamimicking conditions in NCI-H28 cells with the VHL mutation and in MSTO-211H and NCI-H2052 cells without the VHL mutation. Cells were incubated under hypoxic conditions for 2 h or treated with CoCl2 for 18 h. (B) Molecular-targeted agents including YC-1, a HIF-1 $\alpha$ inhibitor, were tested in the NCI-H28 MPM cell line and the IC50 values of 11 inhibitors are shown. $(C)$ The growth-inhibitory effect of $Y C$ - 1 in three MPM cell lines. Significant growth inhibitory effect of YC-1 was observed only in NCI-H28 cells and not in MSTO-211H and NCI-H2O52 cells.

the $\beta$-domain, which is related to the tumor suppressive function of pVHL (Figure 1B). No actionable mutations were detected in the other 47 cancer-related genes (data not shown). Furthermore, we confirmed that the other two mesothelioma cell lines, MSTO-211H and NCI-H2052, did 
A

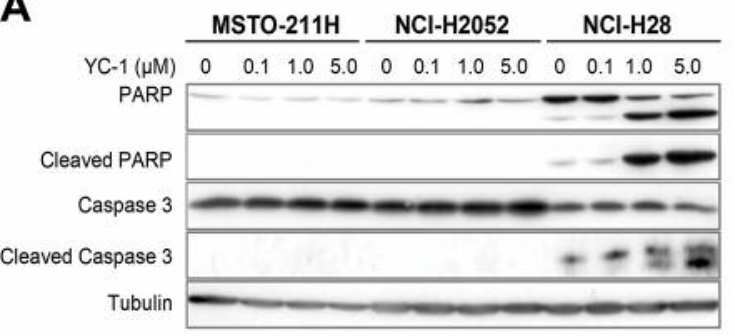

C

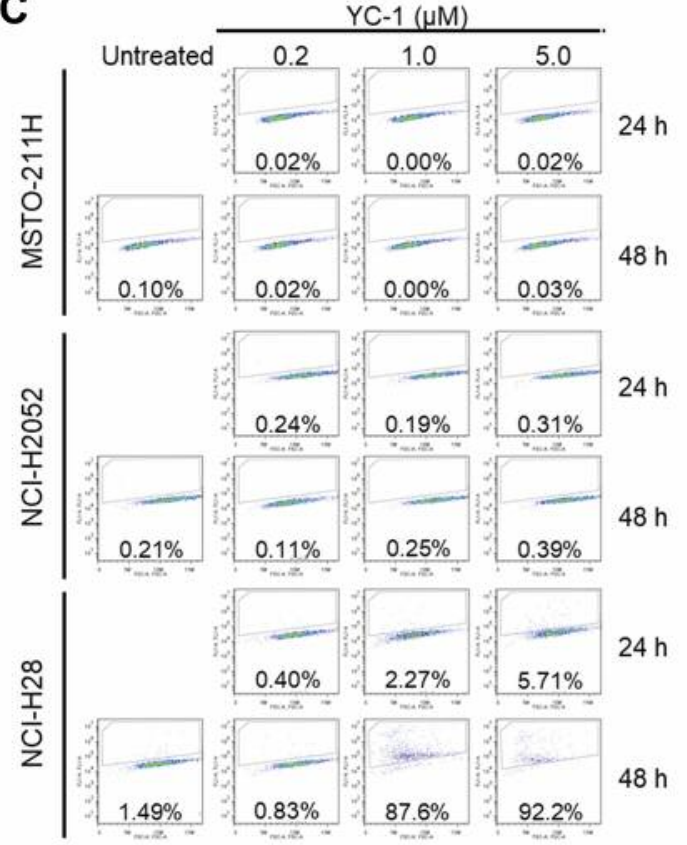

B

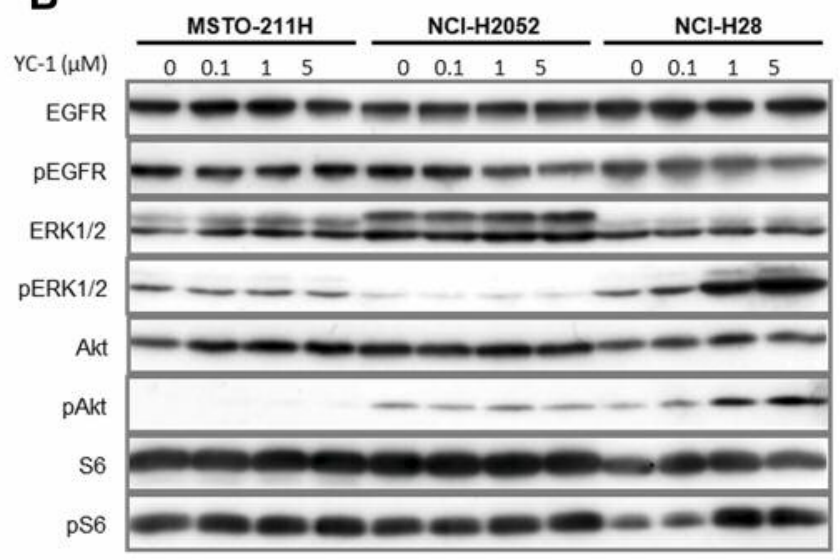

D

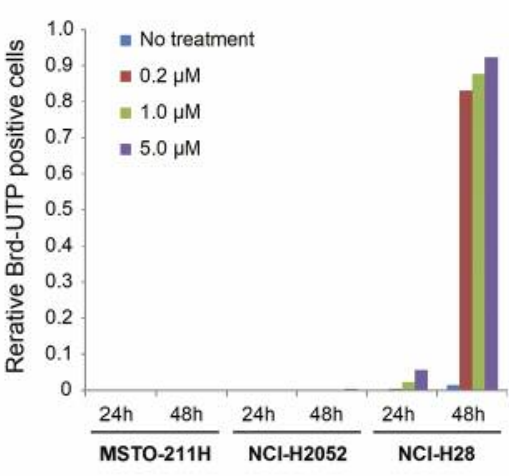

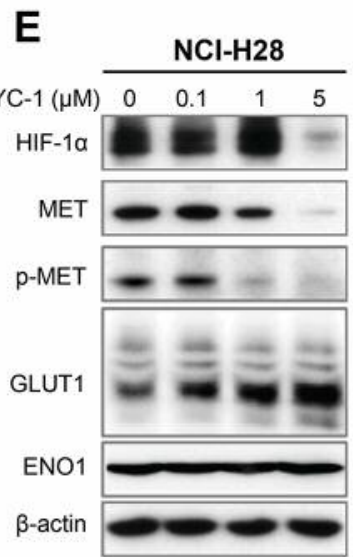

Figure 3. YC-1 induced apoptosis in NCI-H28 cells. (A), (B) The effects of YC-1 were evaluated in three mesothelioma cell lines by western blot analysis. Exposure to YC-1 induced cleavage of both caspase 3 and PARP only in NCI-H28 cells. (C), (D) Induction of apoptosis by YC-1 treatment was measured using the Apo-brdU assay. Cells were treated with YC-1 (0.2, 1, and 5 umol/l) for 24 or 48 h and their number was quantitated using a flow cytometer. The percentage of apoptotic cells (Brd-UTP positive cells) is indicated in the gated area in each panel. The relative numbers of Brd-UTP positive cells are plotted. (E) The effect of YC-1 on molecules downstream of HIF-1 $\alpha$ by western blot analysis NCI-H28 cell extracts.

not exhibit actionable mutations, including the $V H L$ mutation (data not shown). Thus, the NCI-H28 cells were suitable for investigating whether cancer cells with the $V H L$ mutation are dependent on the VHL-related signaling pathway.

$H I F-1 \alpha$ expression and in vitro growth inhibition via the HIF$1 \alpha$ inhibitor. The VHL tumor suppressor regulates the degradation of HIF- $1 \alpha$ by the pVHL/E3 ubiquitin ligase complex, which is crucial for the inhibition of the malignant transformation of cells (23). Thus, if there is loss of functional pVHL due to a genetic disorder, HIF $1-\alpha$ is not targeted for degradation and is consequently up-regulated constitutively (23). Indeed, overexpression of HIF1- $\alpha$ even under normoxic conditions was observed in VHL-mutated NCI-H28 cells (Figure 2A). Meanwhile, HIF-1 $\alpha$ overexpression was also induced under hypoxic conditions and $\mathrm{CoCl}_{2}$-induced hypoxia-mimicking conditions in the other two $V H L$ wild-type MPM cell lines (Figure 2A).

The HIF-1 $\alpha$ inhibitor YC-1 [3-(5'-hydroxymethyl-2'furyl)-1-benzyl indazole] accelerates HIF-1 $\alpha$ degradation and inhibits the de novo synthesis of HIF-1 $\alpha$ by inactivating the phosphatidylinositol 3-kinase/Akt/mammalian target of rapamycin (mTOR) pathway (26). We examined whether HIF-1-overexpressing NCI-H28 cells are sensitive to the HIF-1 $\alpha$ inhibitor YC-1. The half-maximal inhibitory concentration $\left(\mathrm{IC}_{50}\right)$ values of 11 molecular targeting agents including YC-1 are shown in Figure 2B. The growth of NCI-H28 cells was inhibited at the $\mathrm{IC}_{50}$ value of $337 \mathrm{nM}$, which was more than two-fold lower than the concentration of other agents, including tyrosine and serine/threonine 
A
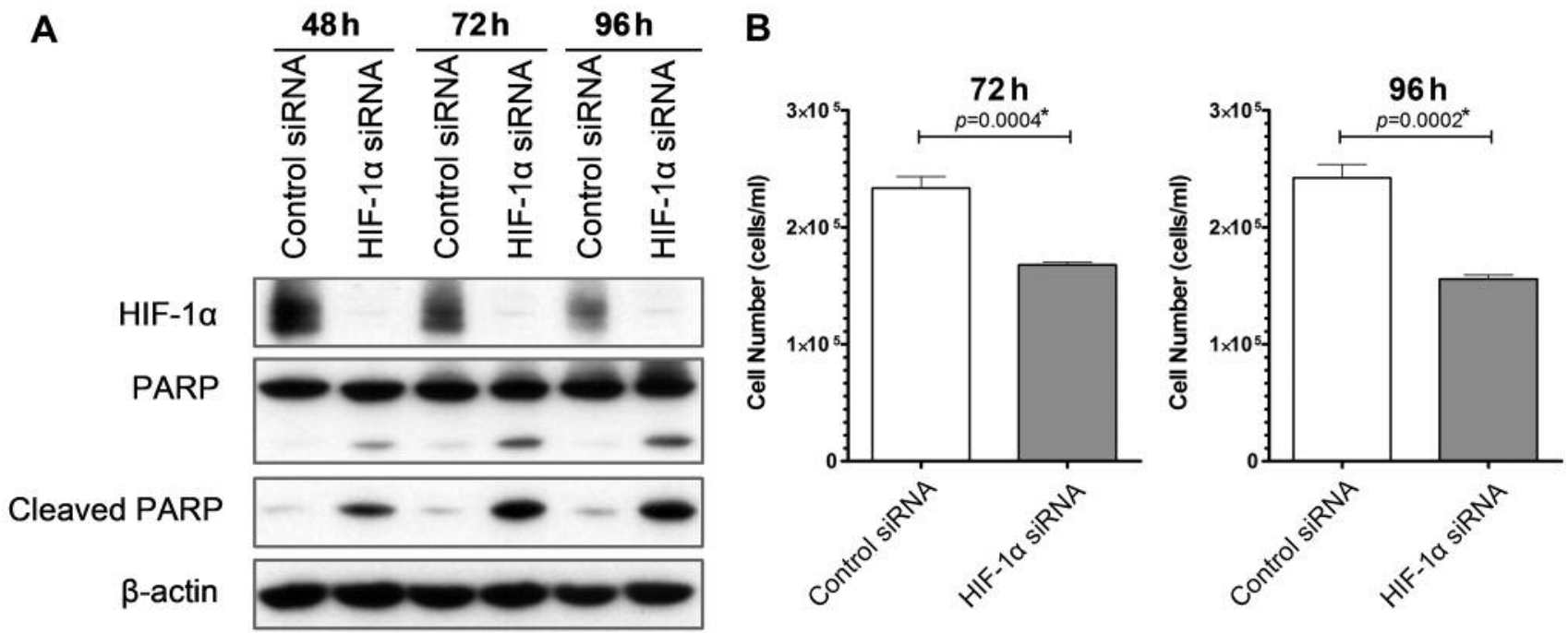

Figure 4. Effect of HIF-1 $\alpha$ silencing using HIF-1 $\alpha$ siRNA in NCI-H28 cells. (A) Expression levels of HIF-1 $\alpha$ in non-treated, control siRNA transfected, and siRNA against HIF-1 $\alpha$-transfected NCI-H28 cells. HIF-1 $\alpha$ expression was successfully abolished by the siRNA targeting HIF-1 $\alpha$. HIF-1 $\alpha$ silencing induced cleaved PARP in NCI-H28 cells. (B) The effect of HIF-1 $\alpha$ silencing on the growth of NCI-H28 cells. Knockdown of HIF$1 \alpha$ by siRNA showed a modest growth inhibitory effect. *Student's two-sided t-test.

kinase inhibitors (Figure 2B). This significant growth inhibitory effect of YC-1 was observed only in NCI-H28 cells and not in VHL wild-type MSTO-211H and NCIH2052 cells (Figure 2C).

YC-1 induce apoptosis of the VHL-mutated MPM cell line. Exposure to $\mathrm{YC}-1$ for $24 \mathrm{~h}$ induced the cleavage of caspase 3 and PARP protein in NCI-H28 cells in a dose-dependent manner (Figure 3A), indicating the induction of apoptosis. This induction of apoptosis was not observed in the other two VHL wild-type cell lines (Figure 3A). Treatment of YC1 did not affect the phosphorylation of EGFR, ERK1/2, Akt, and S6 kinase in MSTO-211H and NCI-H2052 cells (Figure $3 \mathrm{~B})$. In contrast, YC-1 induced the expression of phosphoERK1/2, -Akt, -S6 but did not affect phospho-EGFR expression in NCI-H28 cells (Figure 3B).

Apoptosis induction by $\mathrm{YC}-1$ treatment was confirmed using the APO-BrdU TUNEL assay. Incorporation of $\mathrm{Br}$ dUTP was observed in the NCI-H28 cell line in a dose-andtime-dependent manner, but not in VHL wild-type MSTO$211 \mathrm{H}$ and NCI-H2052 cells (Figure 3C and D).

We next confirmed the effect of YC-1 treatment on HIF$1 \alpha$ expression and molecules downstream of HIF- $1 \alpha$ in NCI$\mathrm{H} 28$ cells. Western blot analysis showed the inhibition of HIF- $1 \alpha$ accumulation by treatment with $5 \mu \mathrm{M}$ YC- 1 (Figure $3 \mathrm{E})$. With respect to molecules downstream of HIF-1 $\alpha, \mathrm{YC}$ 1 treatment abolished the expression of MET protein as well as the phosphorylation of MET (Figure 3E). By contrast, YC-1 had little effect on other downstream molecules such as GLUT1 and ENO1 (Figure 3E).
Silencing HIF-1 $\alpha$ with siRNA. To investigate whether the effects of YC-1 were due to the inhibition of HIF-1 $\alpha$, siRNA targeting HIF-1 $\alpha$ was transfected into NCI-H28 cells, and its effects on cell growth and apoptosis induction were evaluated. Figure 4A shows the successful knockdown of HIF-1 $\alpha$ by the siRNA targeting HIF-1 $\alpha$. The knockdown of HIF-1 $\alpha$ by siRNA induced the cleavage of PARP, indicating the induction of apoptosis (Figure 4A) and significant growth inhibitory effect in NCI-H28 cells, although the effect was not as potent as that of YC-1 (Figure 4B).

\section{Discussion}

Molecular targeted agents have been successfully developed against solid tumors and their use as a treatment for MPM is under investigation. To date, despite preclinical data demonstrating the overexpression of epidermal growth factor receptor (EGFR) and platelet-derived growth factor receptor (PDGFR) in MPM tumor cells, clinical trials have shown no significant benefit from the use of single-agent inhibitors of EGFR, PDGFR, or VEGF. In a phase-I trial examining the efficacy of the histone deacetylase (HDAC) inhibitor, vorinostat, four $(30 \%)$ and two $(15 \%)$ of the 13 patients with MPM demonstrated stable disease and partial response, respectively. However, in the following phase-III trial that compared vorinostat monotherapy and placebo as second-line chemotherapy for MPM, vorinostat did not improve survival (27). Nevertheless, in these studies, some patients responded well to molecular targeted agents. Based on these findings, molecular targeted agents may be effective when administered 
after optimal patient selection, such as selection based on the type of genetic alteration. This study showed that YC-1 might be a potential therapeutic agent for patients with MPM who have the p.Leu89His VHL mutation.

Disruption of $V H L$ by a somatic mutation, hypermethylation of its promoter, or chromosomal loss has been observed in up to $90 \%$ of sporadic clear-cell renal-cell carcinoma cases and pVHL-defective ccRCCs that overexpress mRNAs that are under the transcriptional control of HIF (23). Moreover, overexpression of HIF-1 $\alpha$ in human tumors is associated with poor prognosis and poor therapeutic outcomes (28).

In this study, constitutive overexpression of HIF-1 $\alpha$ was observed in the absence of hypoxia in NCI-H28 cells, which is a mesothelioma cell line carrying the p.Leu89His mutation in VHL. Inhibition of HIF-1 $\alpha$ using YC-1 showed a significant growth inhibitory effect and induction of massive apoptosis in NCI-H28 cells but not in other wild-type VHL MPM cell lines. Whether the effect of YC-1 on growth inhibition in $V H L$ mutated MPM cells is mediated through the inhibition of HIF$1 \alpha$ necessitates further study. In the present study, knockdown of HIF- $1 \alpha$ by siRNA resulted in induction of apoptosis and inhibition of growth of NCI-H28 cells; however, the effect was not as potent as that seen after YC-1 treatment. Based on these results, we hypothesize that HIF- $1 \alpha$ blockade alone may not be sufficient to produce a substantial growth-inhibitory effect in $V H L$ mutation-induced HIF-1 $\alpha$-overexpressing cells. YC-1 is not a selective HIF-1 $\alpha$ inhibitor, and it has been reported that YC-1 can potentially modulate other molecules (29). Although the $V H L$ mutation appears to be a potential therapeutic target of YC-1 treatment in MPM, based on the findings in this study, further investigation is warranted to identify additional molecules that are inhibited by YC-1 and that may serve as more selective therapeutic agents.

Kaira et al. have reported the HIF- $1 \alpha$ expression levels in MPM tissues by immunohistochemistry (30). Positive expression of HIF-1 $\alpha$ was observed in 19 of 21 samples from patients with MPM. Meanwhile, only NCI-H28 cells were sensitive to YC-1 among the three MPM cell lines. Based on these findings, it is suggested that $V H L$-mutation-induced HIF$1 \alpha$ overexpression might be the therapeutic target of YC-1, but HIF-1 $\alpha$ overexpression alone may not be a therapeutic target. MPM cases with $V H L$-mutation-induced HIF- $1 \alpha$ overexpression may behave differently than cases with HIF$1 \alpha$ overexpression without the $V H L$ mutation. Further studies are necessary to clarify this hypothesis and the effects of $\mathrm{YC}$ 1 on other molecules relevant to the VHL-HIF pathway.

Several clinical trials of HIF inhibitors for cancer treatment have been conducted (31). PX-478, a novel HIF-1 $\alpha$ inhibitor, was tested against advanced solid tumors and lymphomas. In the phase-I trial, 41 patients with advanced cancer were enrolled and 13 of the 37 evaluated patients (35\%) had a stable disease (32). The phase-I trial of the novel HIF-1 $\alpha$ RNA antagonist, EZN2968 , has been conducted and interim results have been reported
(33). Prolonged stable disease with clear evidence of tumor shrinkage was observed in one patient with renal cell carcinoma (RCC) and in one patient with hepatocellular carcinoma (34). In the phase-I/IIa trial, CRLX101, a nanoparticle-drug conjugate containing camptothecin and polyethylene glycol that downregulated HIF-1 $\alpha$ expression, was tested against metastatic RCC in combination with bevacizumab; five out of 22 patients (23\%) achieved a partial response (35). The results of a phase-II trial of CRLX101 against recurrent ovarian, fallopian tube, or primary peritoneal cancer have also been reported (36). Digoxin, a cardiac glycoside that inhibits HIF- $1 \alpha$ synthesis, is undergoing a phase-II trial against Kaposi's sarcoma (NCT02212639). Although HIF-1 $\alpha$ inhibitors have been intensely investigated as treatment options for the abovementioned malignancies, thus far, the effect of HIF-1 $\alpha$ inhibitors in patients with MPM has not been reported.

In conclusion, $V H L$-mutant MPM could be targeted by HIF- $1 \alpha$ inhibitors and the $V H L$ mutation might be a promising biomarker for YC-1 treatment. Further investigation is necessary to detect these genetic alterations in a larger cohort and to investigate the effects of $\mathrm{YC}-1$ on other molecules relevant to the VHL-HIF pathway.

\section{Conflicts of Interest}

TS has received grants and personal fees from MSD, personal fees from Ono pharmaceutical company, Chugai pharmaceutical company, AstraZeneca, and Eli Lilly, outside the submitted work.

\section{Authors' Contributions}

Conceptualization: Takehito Shukuya, Yasuhiro Koh; Data curation: Takehito Shukuya, Yasuhiro Koh; Formal analysis: Takehito Shukuya, Masakuni Serizawa, Masaru Watanabe; Funding acquisition: Nobuyuki Yamamoto, Yasuhiro Koh; Investigation: Takehito Shukuya, Masakuni Serizawa, Masaru Watanabe, Yasuhiro Koh; Methodology: Takehito Shukuya, Masakuni Serizawa, Masaru Watanabe, Yasuhiro Koh; Project administration: Yasuhiro Koh; Resources: Yasuhiro Koh; Supervision: Takehito Shukuya, Nobuyuki Yamamoto, Yasuhiro Koh; Visualization: Takehito Shukuya, Yasuhiro Koh; Writing - original draft: Takehito Shukuya, Jun Oyanagi, Yasuhiro Koh; Writing - review \& editing: Takehito Shukuya, Jun Oyanagi, Masakuni Serizawa, Nobuyuki Yamamoto, Yasuhiro Koh.

\section{Acknowledgements}

This work was supported by JSPS KAKENHI Grant Numbers 24591186 (NY), 24501363, 15K06878 (YK), and 25860658 (TS).

\section{References}

1 Pass HI, Vogelzang N, Hahn S and Carbone M: Malignant pleural mesothelioma. Curr Probl Cancer 28(3): 93-174, 2004. PMID: 15197388. DOI: 10.1016/j.currproblcancer.2004.04.001

2 Robinson BW and Lake RA: Advances in malignant mesothelioma. N Engl J Med 353(15): 1591-1603, 2005. PMID: 16221782. DOI: 10.1056/NEJMra050152 
3 Carbone M, Kratzke RA and Testa JR: The pathogenesis of mesothelioma. Semin Oncol 29(1): 2-17, 2002. PMID: 11836664. DOI: $10.1053 /$ sonc.2002.30227

4 Dogan AU, Baris YI, Dogan M, Emri S, Steele I, Elmishad AG and Carbone M: Genetic predisposition to fiber carcinogenesis causes a mesothelioma epidemic in Turkey. Cancer Res 66(10): 5063-5068, 2006. PMID: 16707428. DOI: 10.1158/00085472.Can-05-4642

5 De Luca A, Baldi A, Esposito V, Howard CM, Bagella L, Rizzo P, Caputi M, Pass HI, Giordano GG, Baldi F, Carbone M and Giordano A: The retinoblastoma gene family prb/p105, p107, prb2/p130 and simian virus-40 large t-antigen in human mesotheliomas. Nat Med 3(8): 913-916, 1997. PMID: 9256285. DOI: $10.1038 / \mathrm{nm} 0897-913$

6 Tward JD, Wendland MM, Shrieve DC, Szabo A and Gaffney DK: The risk of secondary malignancies over 30 years after the treatment of non-hodgkin lymphoma. Cancer 107(1): 108-115, 2006. PMID: 16708354. DOI: 10.1002/cncr.21971

7 Gulmez I, Kart L, Buyukoglan H, Er O, Balkanli S and Ozesmi M: Evaluation of malignant mesothelioma in central anatolia: A study of 67 cases. Can Respir J 11(4): 287-290, 2004. PMID: 15254610. DOI: $10.1155 / 2004 / 204793$

8 Vogelzang NJ, Rusthoven JJ, Symanowski J, Denham C, Kaukel E, Ruffie P, Gatzemeier U, Boyer M, Emri S, Manegold C, Niyikiza $\mathrm{C}$ and Paoletti P: Phase iii study of pemetrexed in combination with cisplatin versus cisplatin alone in patients with malignant pleural mesothelioma. J Clin Oncol 21(14): 26362644, 2003. PMID: 12860938. DOI: 10.1200/jco.2003.11.136

9 van Meerbeeck JP, Gaafar R, Manegold C, Van Klaveren RJ, Van Marck EA, Vincent M, Legrand C, Bottomley A, Debruyne C, Giaccone G, European Organisation for R, Treatment of Cancer Lung Cancer $G$ and National Cancer Institute of C: Randomized phase iii study of cisplatin with or without raltitrexed in patients with malignant pleural mesothelioma: An intergroup study of the european organisation for research and treatment of cancer lung cancer group and the national cancer institute of canada. J Clin Oncol 23(28): 6881-6889, 2005. PMID: 16192580 . DOI: 10.1200/JCO.20005.14.589

10 Duffy MJ, O'Donovan N and Crown J: Use of molecular markers for predicting therapy response in cancer patients. Cancer Treat Rev 37(2): 151-159, 2011. PMID: 20685042. DOI: 10.1016/j.ctrv.2010.07.004

11 The Cancer Genome Atlas. Available at: https://www.cancer.gov/ about-nci/organization/ccg/research/structural-genomics/tcga [Last accessed on August 1st 2019]

12 Zehir A, Benayed R, Shah RH, Syed A, Middha S, Kim HR, Srinivasan P, Gao J, Chakravarty D, Devlin SM, Hellmann MD, Barron DA, Schram AM, Hameed M, Dogan S, Ross DS, Hechtman JF, DeLair DF, Yao J, Mandelker DL, Cheng DT, Chandramohan R, Mohanty AS, Ptashkin RN, Jayakumaran G, Prasad M, Syed MH, Rema AB, Liu ZY, Nafa K, Borsu L, Sadowska J, Casanova J, Bacares R, Kiecka IJ, Razumova A, Son JB, Stewart L, Baldi T, Mullaney KA, Al-Ahmadie H, Vakiani E, Abeshouse AA, Penson AV, Jonsson P, Camacho N, Chang MT, Won HH, Gross BE, Kundra R, Heins ZJ, Chen HW, Phillips S, Zhang H, Wang J, Ochoa A, Wills J, Eubank M, Thomas SB, Gardos SM, Reales DN, Galle J, Durany R, Cambria R, Abida W, Cercek A, Feldman DR, Gounder MM, Hakimi AA, Harding JJ, Iyer G, Janjigian YY, Jordan EJ, Kelly CM, Lowery MA, Morris LGT, Omuro AM, Raj N, Razavi P, Shoushtari AN,
Shukla N, Soumerai TE, Varghese AM, Yaeger R, Coleman J, Bochner B, Riely GJ, Saltz LB, Scher HI, Sabbatini PJ, Robson ME, Klimstra DS, Taylor BS, Baselga J, Schultz N, Hyman DM, Arcila ME, Solit DB, Ladanyi M and Berger MF: Mutational landscape of metastatic cancer revealed from prospective clinical sequencing of 10,000 patients. Nat Med 23(6): 703-713, 2017. PMID: 28481359. DOI: 10.1038/nm.4333

13 MSK-IMPACT Clinical Sequencing Cohort (MSKCC, Nat Med 2017). Available at: https://www.cbioportal.org/study/summary? id=msk_impact_2017 [Last accessed on August 1st 2019]

14 Okada M, Kijima T, Aoe K, Kato T, Fujimoto N, Nakagawa K, Takeda Y, Hida T, Kanai K, Imamura F, Oizumi S, Takahashi T, Takenoyama M, Tanaka H, Hirano J, Namba Y and Ohe Y: Clinical efficacy and safety of nivolumab: Results of a multicenter, open-label, single-arm, japanese phase ii study in malignant pleural mesothelioma (merit). Clin Cancer Res 25(18): 5485-5492, 2019. PMID: 31164373. DOI: 10.1158/10780432.CCR-19-0103

15 Quispel-Janssen J, van der Noort V, de Vries JF, Zimmerman M, Lalezari F, Thunnissen E, Monkhorst K, Schouten R, Schunselaar L, Disselhorst M, Klomp H, Hartemink K, Burgers S, Buikhuisen W and Baas P: Programmed death 1 blockade with nivolumab in patients with recurrent malignant pleural mesothelioma. J Thorac Oncol 13(10): 1569-1576, 2018. PMID: 29908324. DOI: 10.1016/j.jtho.2018.05.038

16 Altomare DA, You H, Xiao GH, Ramos-Nino ME, Skele KL, De Rienzo A, Jhanwar SC, Mossman BT, Kane AB and Testa JR: Human and mouse mesotheliomas exhibit elevated akt/pkb activity, which can be targeted pharmacologically to inhibit tumor cell growth. Oncogene 24(40): 6080-6089, 2005. PMID: 15897870. DOI: 10.1038/sj.onc.1208744

17 Suzuki Y, Murakami H, Kawaguchi K, Tanigushi T, Fujii M, Shinjo K, Kondo Y, Osada H, Shimokata K, Horio Y, Hasegawa Y, Hida T and Sekido Y: Activation of the pi3k-akt pathway in human malignant mesothelioma cells. Mol Med Rep 2(2): 181188, 2009. PMID: 21475810. DOI: 10.3892/mmr_00000081

18 Thomas RK, Baker AC, Debiasi RM, Winckler W, Laframboise T, Lin WM, Wang M, Feng W, Zander T, MacConaill L, Lee JC, Nicoletti R, Hatton C, Goyette M, Girard L, Majmudar K, Ziaugra L, Wong KK, Gabriel S, Beroukhim R, Peyton M, Barretina J, Dutt A, Emery C, Greulich H, Shah K, Sasaki H, Gazdar A, Minna J, Armstrong SA, Mellinghoff IK, Hodi FS, Dranoff G, Mischel PS, Cloughesy TF, Nelson SF, Liau LM, Mertz K, Rubin MA, Moch H, Loda M, Catalona W, Fletcher J, Signoretti S, Kaye F, Anderson KC, Demetri GD, Dummer R, Wagner S, Herlyn M, Sellers WR, Meyerson M and Garraway LA: High-throughput oncogene mutation profiling in human cancer. Nat Genet 39(3): 347-351, 2007. PMID: 17293865. DOI: $10.1038 /$ ng 1975

19 Ladanyi M, Zauderer MG, Krug LM, Ito T, McMillan R, Bott $\mathrm{M}$ and Giancotti F: New strategies in pleural mesothelioma: Bap1 and nf2 as novel targets for therapeutic development and risk assessment. Clin Cancer Res 18(17): 4485-4490, 2012. PMID: 22825583. DOI: 10.1158/1078-0432.CCR-11-2375

20 Shukuya T, Serizawa M, Watanabe M, Akamatsu H, Abe M, Imai $\mathrm{H}$, Tokito $\mathrm{T}$, Ono $\mathrm{A}$, Taira $\mathrm{T}$, Kenmotsu $\mathrm{H}$, Naito $\mathrm{T}$, Murakami H, Takahashi T, Endo M, Ohde Y, Nakajima T, Yamamoto $\mathrm{N}$ and Koh Y: Identification of actionable mutations in malignant pleural mesothelioma. Lung Cancer 86(1): 35-40, 2014. PMID: 25174276. DOI: 10.1016/j.lungcan.2014.08.004 
21 Ugurluer G, Chang K, Gamez ME, Arnett AL, Jayakrishnan R, Miller RC and Sio TT: Genome-based mutational analysis by next generation sequencing in patients with malignant pleural and peritoneal mesothelioma. Anticancer Res 36(5): 2331-2338, 2016. PMID: 27127140.

22 Otoshi T, Kataoka Y, Kaku S, Iki R and Hirabayashi M: Prognostic impact of inflammation-related biomarkers on overall survival of patients with inoperable malignant pleural mesothelioma. In Vivo 32(2): 445-450, 2018. PMID: 29475935, DOI: 10.21873 /invivo. 11260

23 Gossage L and Eisen T: Alterations in vhl as potential biomarkers in renal-cell carcinoma. Nat Rev Clin Oncol 7(5): 277-288, 2010. PMID: 20368728. DOI: 10.1038/nrclinonc. 2010.42

24 Sekido Y, Bader S, Latif F, Gnarra JR, Gazdar AF, Linehan WM, Zbar B, Lerman MI and Minna JD: Molecular analysis of the von Hippel-Lindau disease tumor suppressor gene in human lung cancer cell lines. Oncogene 9(6): 1599-1604, 1994. PMID: 8183553.

25 Serizawa M, Takahashi T, Yamamoto N and Koh Y: Combined treatment with erlotinib and a transforming growth factor-beta type I receptor inhibitor effectively suppresses the enhanced motility of erlotinib-resistant non-small-cell lung cancer cells. J Thorac Oncol 8(3): 259-269, 2013. PMID: 23334091. DOI: 10.1097/JTO.0b013e318279e942

26 Li SH, Shin DH, Chun YS, Lee MK, Kim MS and Park JW: A novel mode of action of yc-1 in hif inhibition: Stimulation of fih-dependent $\mathrm{p} 300$ dissociation from hif- 1 \{alpha\}. Mol Cancer Ther 7(12): 3729-3738, 2008. PMID: 19074848. DOI: 10.1158/ 1535-7163.MCT-08-0074

27 Krug LM, Kindler HL, Calvert H, Manegold C, Tsao AS, Fennell D, Öhman R, Plummer R, Eberhardt WEE, Fukuoka K, Gaafar RM, Lafitte J-J, Hillerdal G, Chu Q, Buikhuisen WA, Lubiniecki GM, Sun X, Smith M and Baas P: Vorinostat in patients with advanced malignant pleural mesothelioma who have progressed on previous chemotherapy (vantage-014): A phase 3, double-blind, randomised, placebo-controlled trial. Lancet Oncol 16(4): 447-456, 2015. PMID: 25800891. DOI: 10.1016/s1470-2045(15)70056-2

28 Lee K and Kim HM: A novel approach to cancer therapy using px-478 as a hif-1alpha inhibitor. Arch Pharm Res 34(10): 15831585, 2011. PMID: 22076756. DOI: 10.1007/s12272-011-1021-3

29 Carroll CE, Liang Y, Benakanakere I, Besch-Williford C and Hyder SM: The anticancer agent yc-1 suppresses progestinstimulated vegf in breast cancer cells and arrests breast tumor development. Int J Oncol 42(1): 179-187, 2013. PMID: 23123638. DOI: $10.3892 /$ ijo.2012.1675

30 Kaira K, Serizawa M, Koh Y, Takahashi T, Hanaoka H, Oriuchi $\mathrm{N}$, Endo $\mathrm{M}$, Kondo $\mathrm{H}$, Nakajima $\mathrm{T}$ and Yamamoto $\mathrm{N}$ : Relationship between $18 \mathrm{f}$-fdg uptake on positron emission tomography and molecular biology in malignant pleural mesothelioma. Eur J Cancer 48(8): 1244-1254, 2012. PMID: 22330319. DOI: 10.1016/j.ejca.2012.01.016
31 Fallah J and Rini BI: Hif inhibitors: Status of current clinical development. Curr Oncol Rep 21(1): 6, 2019. PMID: 30671662. DOI: $10.1007 / \mathrm{s} 11912-019-0752-\mathrm{z}$

32 Tibes R, Falchook GS, Hoff DDV, Weiss GJ, Iyengar T, Kurzrock R, Pestano L, Lowe AM and Herbst RS: Results from a phase I, dose-escalation study of px-478, an orally available inhibitor of hif-1 $\alpha$. J Clin Oncol 28(S15), 2009. DOI: 10.1200/jco.2010.28.15_suppl.3076

33 Patnaik A CE, Tolcher A, Papadopoulos K, Beeram M, Kee D, Waddell M, Gilles E, Buchbinder A: Ezn-2968, a novel hypoxiainducible factor- $1 \alpha$ (hif- $1 \alpha$ ) messenger ribonucleic acid (mrna) antagonist: Results of a phase I, pharmacokinetic (pk), doseescalation study of daily administration in patients (pts) with advanced malignancies. J Clin Oncol 27(S15), 2009. DOI: 10.1200/jco.2009.27.15_suppl.2564

34 Lewis N, Cohen RN, Nishida Y, Hurwitz HI, Arrowwood C, Uronis HE, Gilles E, Longley C, Buchbinder A and Figueroa J: Phase I, pharmacokinetic (PK), dose-escalation study of EZN2968, a novel hypoxia-inducible factor- $1 \alpha$ (HIF-1 $\alpha$ ) RNA antagonist, administered weekly in patients (pts) with solid tumors, EORTC-NCI-AACR 2008, Switzerland. Available at: http://enzon.com/files/HIF1a-2.pdf [Last accessed on March 5th 2020]

35 Keefe SM, Hoffman-Censits J, Cohen RB, Mamtani R, Heitjan D, Eliasof S, Nixon A, Turnbull B, Garmey EG, Gunnarsson O, Waliki M, Ciconte J, Jayaraman L, Senderowicz A, Tellez AB, Hennessy M, Piscitelli A, Vaughn D, Smith A and Haas NB: Efficacy of the nanoparticle-drug conjugate crlx101 in combination with bevacizumab in metastatic renal cell carcinoma: Results of an investigator-initiated phase I-IIa clinical trial. Ann Oncol 27(8): 1579-1585, 2016. PMID: 27457310. DOI: $10.1093 / \mathrm{annonc} / \mathrm{mdw} 188$

36 Duska L, O'Malley DM, Krasner C, Schilder RJ, Mathews C, Moore K, Thaker P, Miller A, Purdy C, Leyco AJ, Smith C, Mercier D, Tennant L, Kennedy E, Vahanian N and Link C: CT151/17 - A Phase II study of NLG207 (formerly CRLX101) in combination with weekly paclitaxel in patients with recurrent or persistent epithelial ovarian, fallopian tube or primary peritoneal cancer, AACR Annual Meeting, Atlanta, GA, USA, 2019. DOI: 10.1158/1538-7445.AM2019-CT151 